Canadian Studies in Population, Vol. 32.1, 2005, pp. 53-67

\title{
Living Arrangements among Single Mothers in India
}

\author{
Pushpanjali Swain \\ Department of Statistics and Demography \\ National Institute of Health \& Family Welfare \\ Munirka, New Delhi 110 067. India \\ Vijayan K. Pillai \\ School of Social Work \\ University of Texas at Arlington \\ Arlington, Texas., USA
}

\begin{abstract}
:
A large proportion of two parent households transition into single parent households upon marital disruption. Single parent households, especially female headed households face an increase in the risk of poverty. This study focuses on whether widow status in India influences the likelihood of household headship in India. This study is based on the most recent National Family Health Survey 1998-1999, in India. The population of interest includes all mothers aged 15 to 49 years, without a spouse, living with one or more of their own children under 18 years of age. We find that being a widow increases the likelihood of being a household head compared to the likelihood of household headship among the divorced and the separated in India. This study provides some evidence on the continuing social discrimination against widows in India. The implication of the findings are discussed.
\end{abstract}

Key Words: Single mothers, poverty, living arrangements, widowhood, household headship 
Pushpaniali Swain and Vijayan K. Pillai

\section{Résumé:}

Une grande proportion des ménages biparentaux se transforme en ménages monoparentaux après une séparation maritale. Les ménages monoparentaux, spécialement ceux qui sont dirigés par une femme, font face à un danger plus élevé de sombrer dans la pauvreté. Cette étude examine à quel point le fait d'être veuve influence la probabilité de se retrouver à la tête d'un ménage en Inde. Cette étude est basée sur le recensement sur la santé des familles de 19981999, le plus récent en Inde. La population d'intérêt comprend toutes les mères âgées de 15 à 49 ans, sans époux et qui vivent avec au moins un de leurs propres enfants de moins de 18 ans. Nous avons trouvé qu'en Inde, le fait d'être veuve augmente la probabilité qu'une femme se retrouve à la tête de son ménage en comparaison aux femmes divorcées ou séparées. Cette étude avance des preuves de cette discrimination sociale continue en Inde envers les veuves. Les implications de ces constatations sont discutées.

Mots clés : Les mères célibataires, les conditions de logement, le veuvage, la direction des ménages.

\section{Introduction}

Perhaps one of the most important issues of concern to social welfare workers and policy makers in the developing countries today is the exponential rise in single parent households (DeVos and Arias,1998). When marriage dissolves because of the death of a spouse, divorce or separation, existing living arrangements change. The risk of being a single parent head-of-household increases with marital dissolution. When the husband is the major source of income, marital dissolution increases the likelihood of poverty among women head-of-households. In addition to gender, there other cultural factors that increase the chance of head of hold status among single women.

With marital dissolution women suffer from considerable loss of social status as indicated by an increase in female headship. The husband is recognized as the head of the household and the wife's role as a head of the household is socially disapproved (Bhandari, 2004). In India, head-of-household status among women brings about several disadvantages First, the household becomes economically vulnerable. Households in poverty have very little protection owing to the lack of public assistance programs such the Temporary Assistance for Needy families 
in the United States. Second, women heads of household suffer form social isolation which results from the loss of social bonds that are created by alliances resulting from marriage. A large proportion of Indian nuclear families is not 'structurally isolated' (Parson, 1943) from the families of origin. Often unmarried kin of the husband may also live in the household to attend schools in urban areas. Furthermore, new nuclear households become multigenerational as sons assume the responsibility of caring for aging parents. Thus, in general, nuclear families maintain strong ties with the family of origin as well as with kinfolk in reciprocal and mutually supportive relationships (Rani, 1978; Srivastava, 1986).

In India, divorce and marital separation are socially disapproved and widows suffer from social discrimination even today. There has been a slight increase in divorce rates in India during the last decade. The percent divorced was 0.74 percent in 1991 and 1.00 percent in 2001 (Census of India, 2001). Social discrimination of widows has been an age old problem in India. In this paper we argue that Indian widows are more likely to become household heads than the divorced and separated. Female head-of-households who are widows are also more likely to experience poverty than head-of-households who are divorced or separated.. The difference in headship rates between widowed and divorced/separated women is generally small. However in a few countries such as Bangladesh and Myanmar where headship rate for widows exceeds that for divorced/separated women by more than 30 points (United Nations, 1995). Since women usually have limited economic, social and educational resources available to them, it is assumed that the unequal social position of female heads compared to males may create negative effects on the welfare of the family. In particular, children may lack access to sufficient resources when they live in female-headed households.

The purpose of this paper is to examine the variations in household headship status among women who have experienced marital disruption in India. In particular, we focus on the effect of widowhood on the household head status.

\section{Household Headship and Widowhood in India: An Explanation}

A number of cultural factors limit widows from full participation in the social life of the community. Chakravarti (1998) cites at least four aspects of social exclusion of widows in India. First, widows are expected to withdraw themselves from public gaze and public participation as much as possible. She is expected to be virtuous and remain home as much as possible and submit herself to surveillance by elder members of the family. Second, she is expected to 
Pushpaniali Swain and Vijayan K. Pillai

remain unmarried and refrain from sexual activities the rest of her life. To mark her lack of interest in sex, she is expected to wear white clothing and to forgo ornaments such as bangles. Third, she is restricted even from participating in domestic ceremonies that women perform in the household. Finally, she is not to assert her rights to property, if any, left behind by her deceased husband.

In the presence of these restrictions, widows in India are extremely vulnerable to poverty and their only escape from the extreme form of culturally sanctioned social ostracism is to become independent. A large proportion of widows in urban India look for independence by seeking employment and becoming household heads. Even though the divorced and separated are not socially approved, they do not suffer from social stigma as much as the widows in India. Thus widows are far more likely to be head-of-households than the divorced and the separated..

The age at which marital disruption occurs influences the likelihood of female household headship. When marital disruption occurs at a young age, the woman is to be protected by her near or extended relatives. This is because the so called nuclear families in India are seldom totally independent. Household decisions are often influenced by the extended family (Mehrotra, 2003). At young ages, women are more likely to have young children at home. These young mothers may seek employment to support themselves. However they are often protected from being female head-of-households and are more likely to stay with a close relative who is a household head. In general, young women who have experienced marital disruption (divorce, separation or widowhood) are less likely to be female heads-of-household than other women.

The protective effect of being a young woman who has experienced marital disruption is not the same across all categories of women. In particular, the high degree of ostracism that widows suffer in India today is likely to leave the young widow vulnerable and increase her likelihood of being a household head compared to the divorced and separated. We argue that young widows as a group are far more likely to be heads-of-households than the divorced and separated in India. If this hypothesis is supported, it may present one more shred of empirical evidence of the persistent social discrimination experienced by Indian widows today.

In sum, we present three hypotheses to characterize the social discrimination faced by widows in India. First, widows are more likely to be female household heads than the divorced and the separated. Second, young women who have experienced marital disruption are less likely to be female household heads compared to older women. Finally, young widows are far more likely to experience female headship than the rest. 
Living Arrangements among Single Mothers in India

The literature on living arrangements among women whose marriages have disrupted is indeed small. Existing studies present empirical support for a few variables that are significantly associated with female headship in India (Buvinic and Rao, 1997; Drèzea and Srinivasan, 1997). These variables are job status, place of residence (rural or urban), educational level, and the presence of young children. Working women are more likely to be able to set up their own households. As a result they are more likely to be household heads than those who are not working (Rukmini, 1998). Urban women tend to be more modern and espouse modern ideas of independence and freedom than rural women. Consequently, women who have experienced marital disruption and are living in urban areas are more likely to be household heads than rural women. As education level increases, women are more likely to value autonomy. Consequently, educational level has a positive relationship with the likelihood of female headship. Women with young children at home are constrained by the enormous amount of time spent on childcare and socialization. As a result, when young children are present, women may opt for a living arrangement where they have access to family support needed for child care. Women with young children are therefore less likely to be female heads-of-households.

\section{Methods and Material}

This study is based on the most recent National Family Health Survey 19981999, in India. The population of interest includes all mothers aged 15 to 49 years, without a spouse, living with one or more of their own children under 18 years of age. The sample includes, therefore, women in three different marital statuses 'divorced', 'separated' and 'widowed'. The sample consists of 3334 women, among whom 2400 are widows and the remaining are 'divorced' or 'separated'. The separated include women who have been deserted.

The dependent variable is "whether the sample respondent is head of the household or not 'at the time of interview.' It is a dichotomous variable (head) and is coded 1 if the respondent is a household head. The independent variables are age, and marital status. Age is a binary variable (age) with respondents at or below 35 years of age coded 1 and the rest are coded 0 . All the women in the sample belong to any of the three marital states; divorce, separated and widowed. A binary variable, widow, is created in which all the widows are coded 1 and the rest 0 . In addition, to the two variables a third variable (widyoung) an interaction variable was created with the two variables age and widow. This is a dichotomous variable, with widows at or below age 35 coded 1 and the rest zero. 
Pushpaniali Swain and Vijayan K. Pillai

The control variables in this study are 'Working', 'Baby', 'Rural', and 'Education'. The variable 'Working' is a binary variable coded 1 if the respondent is working. The variable 'Baby' is also a binary variable coded 1 if the respondent has child less than 12 years of age living with her. If the place of residence is rural, the variable 'rural' is coded 1, otherwise 0. Finally, respondents are grouped into four categories of education; illiterate, primary school level, secondary school, and higher levels of schooling. The last category, 'higher', is the reference group. The logistic regression model is used to assess the empirical validity of the proposed hypotheses in this study.

\section{Results}

We find that more than half $(51 \%)$ of all women with children are heading their own households. Of those not heading their own households, more than one quarter $(28 \%)$ are living with their parents or parents-in-law and one-tenth are living as parents and one tenth are living with other relatives. The proportion of women living with non-relatives is negligible. In sum, almost $80 \%$ of the single women hold the position of heads and daughters.

Disaggregating the total number of women with children into categories by the age of the youngest child and the number of children, we find that there are wide differences in the distributions of relationships to the head of the household. Table 1

reveals that there is a strong positive relationship between age of the youngest child and the probability that a woman is a household head. While only $22 \%$ of mothers whose youngest child is under 3 years of age are heads, $61 \%$ of mothers whose youngest child is over 11 years are household heads. Regardless of the age of the youngest child, with an increase in the number of children, there is an increase in the proportion of household heads. Among women whose youngest child is under the age of three, there is only $4 \%$ with one child in comparison to $35 \%$ with two or more children are heads. In contrast, among mothers whose youngest child is over 11 years, the proportion of household heads varied from $45.4 \%$ to $64.6 \%$ for those having two or more children.

Women, who are not head-of-household, are highly likely to reside with their parents. The proportion of women who live with their parents is greater for women having fewer children. Women with young children are more likely to stay with their parents than women with older children. The proportion of women living with their parents was $84 \%$ among those with one child under the age of three, but only $10 \%$ among mothers with 2 or more children whose youngest child is older than age 11 . 


\section{Table 1: Living Arrangements by Mothers with Children under 18 and Number of Children}

\begin{tabular}{|c|c|c|c|c|c|c|c|}
\hline \multicolumn{2}{|c|}{$\begin{array}{c}\text { Age and Number } \\
\text { of the } \\
\text { Youngest Child }\end{array}$} & \multirow{2}{*}{$\begin{array}{c}\text { Head } \\
4.2\end{array}$} & \multirow{2}{*}{$\begin{array}{c}\begin{array}{c}\text { Daughter } \\
\text { of head }\end{array} \\
83.9\end{array}$} & \multirow{2}{*}{$\begin{array}{c}\begin{array}{c}\text { Parent of } \\
\text { head }\end{array} \\
---\end{array}$} & \multirow{2}{*}{$\begin{array}{c}\text { Other }^{3} \\
\text { relatives }\end{array}$} & \multirow{2}{*}{$\begin{array}{c}\begin{array}{c}\text { Non } \\
\text { relatives }\end{array} \\
---\end{array}$} & \multirow{2}{*}{$\begin{array}{c}\begin{array}{c}\text { Total } \\
\text { percent }\end{array} \\
100.0\end{array}$} \\
\hline$\overline{0-2}$ & One child & & & & & & \\
\hline & $\begin{array}{l}\text { More than } 2 \\
\text { children }\end{array}$ & 34.6 & 55.9 & 1.1 & 8.5 & --- & 100.0 \\
\hline & Total & 21.5 & 68.0 & .6 & 10.0 & --- & 100.0 \\
\hline \multirow[t]{3}{*}{$3-5$} & One child & 17.0 & 64.3 & & 17.0 & 1.8 & 100.0 \\
\hline & $\begin{array}{l}\text { More than } 2 \\
\text { children }\end{array}$ & 49.3 & 38.1 & 1.8 & 10.3 & .6 & 100.0 \\
\hline & Total & 41.2 & 44.6 & 1.3 & 12.0 & .9 & 100.0 \\
\hline \multirow[t]{3}{*}{$\overline{6-11}$} & One child & 27.2 & 54.3 & .8 & 17.4 & .4 & 100.0 \\
\hline & $\begin{array}{l}\text { More than } 2 \\
\text { children }\end{array}$ & 59.3 & 19.0 & 12.8 & 8.7 & .2 & 100.0 \\
\hline & Total & 52.5 & 26.5 & 10.3 & 10.5 & .2 & 100.0 \\
\hline \multirow[t]{3}{*}{$\begin{array}{l}12 \text { and } \\
\text { above }\end{array}$} & One child & 45.4 & 32.3 & 1.7 & 18.8 & 1.7 & 100.0 \\
\hline & $\begin{array}{l}\text { More than } 2 \\
\text { children }\end{array}$ & 64.6 & 10.3 & 18.2 & 6.6 & .4 & 100.0 \\
\hline & Total & 61.2 & 14.2 & 15.3 & 8.7 & .6 & 100.0 \\
\hline \multicolumn{2}{|c|}{ Total percent } & 51.2 & 28.3 & 10.0 & 10.0 & 0.5 & 100.0 \\
\hline & Number & 1708 & 942 & 334 & 333 & 15 & 3332 \\
\hline
\end{tabular}

Source: National family health survey 1998-99

${ }^{1}$ Includes daughter-in-law

${ }^{2}$ Includes parent-in-laws

${ }^{3}$ Includes brother, uncle, grand parents etc. 
Pushpaniali Swain and Vijayan K. Pillai

Though other types of living arrangements, such as living with other relatives, are not very common, they are also associated with age and number of children. The highest proportion of women living with the households headed by other relatives is found among mothers with one child in the age group of children 35, 6-11 and 12-17 years. The proportion of women who are mothers of the household heads reached a high up to $18 \%$ among mothers whose youngest child is $12-17$ years of age.

There are several explanations for these findings. The mothers of the older children are less constrained than the mothers of younger children because of the need to arrange for childcare. Thus, they are more likely to work to maintain their own household. Secondly, the mothers of the older children are older themselves. They are more independent in decision making for their family. They may have had a longer period of time to make a more permanent economic adjustment to their status of single mother. They may have less access to their own parents. Mothers of older children are more likely to be willing to work outside the home to earn a livelihood. Lastly, mothers of the youngest children (more than 11 years) are likely to have many children and thus may have more difficulty doubling up with relatives.

Mothers of younger children may be younger themselves and have a greater chance of living with their parents. It is difficult for mothers of younger children to work outside, attend to the demands of children and to maintain one's own household. Generally these women may prefer to live with parents or other relatives. It is noteworthy to mention here that a woman is easily accommodated by relatives or parents if she does not have several children.

Overall $59 \%$ of the widows are household heads, whereas only $39 \%$ of the divorced and $29 \%$ of the separated women are in the headship position. See Table 2.

However the difference in headship rates narrows with the increase of the age of the children under each marital status. The higher headship among widows suggests that after the death of the husband, they make the decision to live with children independently since the possibility of remarriage is not common in India. Only widows with young children return to their parent's house. Widows are generally more likely to be heads because widows with children are not welcome in the home of the in-laws for fear that she may claim a share of the inlaw's property. The chance of mistreatment by her in-laws is higher due to the socio-cultural milieu. She also hesitates to return to her own parents, to avoid being a burden to them. 
Table 2

Distribution of Mothers by Marital Statuses related to Household Head by Age of the Youngest Child

\begin{tabular}{|c|c|c|c|c|c|c|c|c|}
\hline $\begin{array}{c}\text { Current } \\
\text { Marital } \\
\text { Status } \\
\end{array}$ & $\begin{array}{c}\text { Age of } \\
\text { Youngest } \\
\text { Child } \\
\end{array}$ & Head & $\begin{array}{c}\text { Daughter }^{1} \\
\text { of Head }\end{array}$ & $\begin{array}{c}\text { Parent } t^{2} \text { of } \\
\text { Head }\end{array}$ & $\begin{array}{c}\text { Other }^{3} \\
\text { Relatives }\end{array}$ & $\begin{array}{c}\text { Non } \\
\text { Relatives }\end{array}$ & $\begin{array}{c}\text { Sample } \\
\text { Size }\end{array}$ & Total \\
\hline \multicolumn{9}{|l|}{ Widowed } \\
\hline & $0-2$ & 34.7 & 53.2 & 1.6 & 10.5 & --- & 124 & 100.0 \\
\hline & $3-5$ & 54.5 & 32.0 & 2.3 & 10.5 & 0.8 & 266 & 100.0 \\
\hline & $6-11$ & 58.4 & 19.3 & 12.7 & 9.2 & 0.3 & 967 & 100.0 \\
\hline & $12+$ & 63.4 & 11.1 & 17.5 & 7.5 & 0.6 & 1070 & 100.0 \\
\hline $\begin{array}{c}\text { Total } \\
\text { Percent }\end{array}$ & & 59.0 & 18.8 & 13.1 & 8.7 & 0.5 & 2427 & 100.0 \\
\hline \multicolumn{9}{|l|}{ Divorced } \\
\hline & $0-2$ & 18.2 & 81.8 & --- & & --- & 11 & 100.0 \\
\hline & $3-5$ & 21.7 & 69.6 & --- & 8.7 & --- & 23 & 100.0 \\
\hline & $6-11$ & 42.9 & 38.6 & 4.3 & 14.3 & --- & 70 & 100.0 \\
\hline & $12+$ & 47.2 & 33.3 & --- & 16.7 & 2.8 & 36 & 100.0 \\
\hline $\begin{array}{c}\text { Total } \\
\text { Percent }\end{array}$ & & 38.6 & 45.7 & 2.1 & 12.9 & 0.7 & 140 & 100.0 \\
\hline \multicolumn{9}{|c|}{ Not Living Together } \\
\hline & $0-2$ & 12.8 & 76.9 & --- & 10.3 & --- & 195 & 100.0 \\
\hline & $3-5$ & 22.6 & 61.6 & --- & 14.6 & 1.2 & 164 & 100.0 \\
\hline & 6-11 & 28.9 & 54.1 & 1.8 & 15.1 & --- & 218 & 100.0 \\
\hline & $12+$ & 51.3 & 27.7 & 5.8 & 14.7 & 0.5 & 191 & 100.0 \\
\hline $\begin{array}{c}\text { Total } \\
\text { Percent }\end{array}$ & & 29 & 54.9 & 2.0 & 13.7 & 0.4 & 768 & 100 \\
\hline
\end{tabular}

Source: National family health survey 1998-99

${ }^{1}$ Includes daughter-in-law

${ }^{2}$ Includes parent-in-laws

${ }^{3}$ Includes brother, uncle, grand parents etc. 
Pushpaniali Swain and Vijayan K. Pillai

It is worth noting that $70 \%$ of divorced mothers and $77 \%$ of separated women with children under age 3 are living with parents. The possible explanation is that mothers of the younger children under age 3 would be so young that they would not have sound financial resources to maintain an independent living arrangement and are forced to live with parents. Indian parents generally arrange marriages for their children. Therefore, parents are blamed if the marriages are not successful. Further analysis reveals that even then, 9\% of widows live with the mother-in-law's family. However, only $4 \%$ separated women are living with their mother-in-law's family.

\section{Multivariate Analysis}

Table 3 presents the logistic regression results. All variables selected for analysis are significant. As expected, young respondents, those below 35 years of age are less likely to head a household compared to those older than 35 . The odds of headship are about 80 percent lower for the younger women compared to odds of headship for women older than 35 . The odds of household headship among women are about 33 percent greater than the odds of headship among women who either divorced or separated. This result provides empirical support for the proposed hypothesis with respect to the risk of headship among widows in India. Finally, the interaction variable, 'widyoung', is significant at the .05 level. The odds of young widows assuming household headship are about three times greater than the odds of headship among the rest of respondents in the sample.

In general, the results of this study provide empirical support for our hypothesis of social discrimination against widows in India. While the odds of headship among young women are less compared to older women, among young widows the odds of headship, net of other factors, was at least three times greater than the rest.

It is assumed that 'female headship' is associated with a lower standard of living (Dreze and Srinivan, 1998). The hypothesis of social discrimination rests on the belief that head ship is associated with lower standard of living and that for widows headship is a pathway to a low standard of living. This hypothesis is tested by regressing 'standard of living' on the three independent variables, 'age' and 'widows' and 'headship status' and all the control variables. The regression results are presented in Table 4. Female headship has a significant effect on standard of living. The odds of female household heads being in the low standard of life category is about 2.4 time greater than the odds for those women who are not female heads. In general our results point to social discrimination against widows in India. The discrimination is institutionalized 
Table 3

Logistic Coefficients and Odds Ratio of Heading a Household by Single Mothers

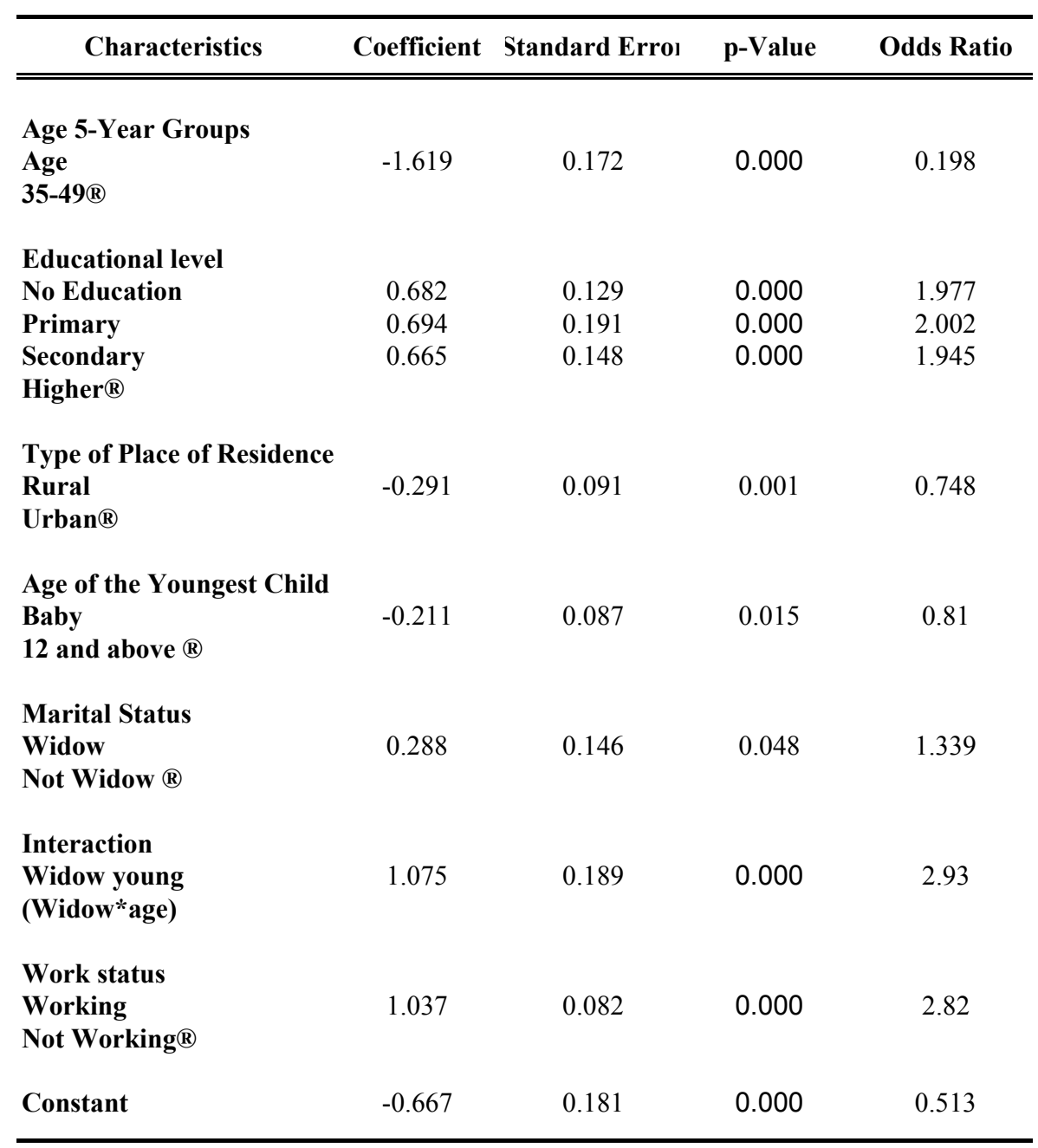

( : reference category 
Pushpaniali Swain and Vijayan Pillai

Table 4

Logistic Coefficients and Odds Ratio of Poor Standard of Living among Single Mothers

\begin{tabular}{|c|c|c|c|c|}
\hline Characteristics & Coefficient & Standard Error & p-Value & Odds Ratio \\
\hline $\begin{array}{l}\text { Age 5-Year Groups } \\
\text { Age } \\
35-49 \circledR\end{array}$ & 0.455 & 0.096 & 0.000 & 1.576 \\
\hline $\begin{array}{l}\text { Educational level } \\
\text { No Education } \\
\text { Primary } \\
\text { Secondary } \\
\text { Higher }{ }^{\circledR}\end{array}$ & $\begin{array}{l}2.098 \\
1.628 \\
0.998\end{array}$ & $\begin{array}{c}0.172 \\
0.221 \\
0.19\end{array}$ & $\begin{array}{l}0.000 \\
0.000 \\
0.000\end{array}$ & $\begin{array}{l}8.151 \\
5.096 \\
2.686\end{array}$ \\
\hline $\begin{array}{l}\text { Type of Place of Residence } \\
\text { Rural } \\
\text { Urban }{ }^{\circledR}\end{array}$ & 1.037 & 0.097 & 0.000 & 2.82 \\
\hline $\begin{array}{l}\text { Age of the Youngest Child } \\
\text { Baby } \\
12 \text { and above }{ }^{\circledR}\end{array}$ & 0.14 & 0.092 & 0.127 & 1.151 \\
\hline $\begin{array}{l}\text { Marital Status } \\
\text { Widow } \\
\text { Not Widow }{ }^{\circledR}\end{array}$ & -0.355 & 0.098 & 0.000 & 0.701 \\
\hline $\begin{array}{l}\text { Interaction } \\
\text { Widow young } \\
\text { (Widow*age) }\end{array}$ & 0.935 & 0.086 & 0.000 & 2.546 \\
\hline $\begin{array}{l}\text { Work status } \\
\text { Working } \\
\text { Not Working® }\end{array}$ & 0.781 & 0.086 & 0.000 & 2.183 \\
\hline Constant & -3.59 & 0.208 & 0.000 & 0.028 \\
\hline
\end{tabular}

(R) : reference category 
and has deep roots in the cultural milieu of Indian society. In spite of several attempts by governmental and non governmental agencies to eradicate social discrimination, several of the anti discimination campaigns have not met with much success.

\section{Conclusion}

Marital disruption is a well known factor in the production of single parent households. Slightly more than half, fifty one percent, of all the women with children who experienced marital disruption in our sample became household heads. Women with young children were more likely to stay with their parents than women with older children . Only $22 \%$ of mothers whose youngest child was under 3 are household heads. The proportion of women living with parents reached 84 percent among those with one child under the age of three. These results suggest that when marital disruption occurs, the family of origin and close relatives come to the rescue. Families play a crucial role in providing assistance in the absence of government sponsored welfare programs to support the mothers who become poor after marital disruption.

Widows are more likely to become heads-of-households than the divorced and the separated. Overall, 59\% of the widows are household heads, whereas only 39 percent of the divorced, and 29 percent of the separated women are in the headship position. More specifically young widows are the most likely to become household heads than the rest. Widows have long experienced social discrimination in India. Mortality rates among widows in the 45 plus age group are $85 \%$ higher than those for married women in the same age group (Bhatt, 1998.). According to Chen (1998), there are more than 33 million widows in India, comprising about 8 percent of the total female population of the country. The results from multivariate analysis suggest that the variables, 'age', 'widow status', and being a young widow are important determinants of a headship position. Being the head of a household is less of a privilege and more of a challenge for single mothers.

With the availability of employment, a large proportion of widows now choose to become heads-of-households to escape from social and culturally sanctioned ostracism. However, it is found that among women who experience marital disruption, the standard of living of heads-of-households appears to be lower than women who are not head-of-households. This study then presents some evidence to speculate that widows in India are in the process of becoming a publicly visible category of the poor while traditionally they have remained socially oppressed and invisible. This transformation presents opportunities for 
Pushpaniali Swain and Vijayan K. Pillai

social policy makers, social workers and social reformers to launch social action programs to improve the welfare of widows in India.

\section{References:}

Bhandari, Mala. (2004). Women in two work roles and the quality of their life. Sociological Bulletin 53(1): 94-104

Bhatt, Mari. (1998). Widowhood and Mortality in India. Chen, Martha (Ed.). Windows in India: social neglect and public action. New Delhi :Sage Publications.

Buvinic, Mayra; Gupta, Geeta Rao. (1997.). Female-headed households and female-maintained families: Are they worth targeting to reduce. Economic Development and Cultural Change 45(2): 259-271.

Census of India. (2001). Socio-Cultural Table of Census 1991 2001. New Delhi: Registrar general of India.

Chakravarti, Uma. (1998). "Gender, caste and labour" in The ideological and material structure of widowhood. Chen, Martha (Ed.). Windows in India: Social Neglect and PublicAaction. New Delhi :Sage Publications

Chen, Martha. (1988). Introduction. Chen, Martha (Ed.). Windows in India: Social Neglect and Public Action. New Delhi :Sage Publications.

De Vos, Susan and Arias, Elizabeth. (1998). Female Headship, Marital Status and Material Well-Being: Colombia 1985. International Journal of Comparative Sociology 39(2): 177-197

Drezea, Jean and Srinivasan, P.V. (1998). Widowhood and poverty in rural India: Some inferences from household survey data. Chen, Martha (Ed.). Windows in India: Social Neglect and Public Action. New Delhi Sage Publications

Drèzea, Jean and Srinivasan, P V. (1997). Widowhood and poverty in rural India: Some inferences from household survey data. Journal of Development Economics 54(2): 217-234.

Mehrotra, Deepti. (2003). Home Truths: Stories of Single Mothers. New Delhi: Penguin. 
Living Arrangements among Single Mothers in India

Parson, Talcott. (1943). The kinship system of the contemporary United States. American Anthropologists 45: 22-38.

Rani, Kala. (1978). Role Conflict in Working Women. New Delhi: Chetna Publications.

Rukmini, D.V. (1998). Women's employment status by marital status. Chen, Martha (Ed.). Windows in India: Social Neglect and Public Action. New Delhi :Sage Publications.

Srivastava, A.K. (1986). Social Class and Family Life in India. Delhi: Chugh Publications.

United Nations. (1995). Living Arrangements of Women and their Children in Developing Countries: A Demographic Profile. New York: United Nations. 